\title{
Paparan Asap Rokok terhadap Sindrom Mata Kering pada Mahasiswa UPN “Veteran" Jakarta
}

\author{
Kristina Simanjuntak ${ }^{1, *}$, Devi Handayani Putri², Nurina Mutia Farah ${ }^{2}$ \\ ${ }^{1}$ Departemen Biokimia Fakultas Kedokteran Universitas Pembangunan Nasional "Veteran" \\ Jakarta \\ ${ }^{2}$ Departemen Mata Fakultas Kedokteran Universitas Pembangunan Nasional "Veteran" \\ Jakarta \\ *Correspondence author: kristin_juntak@yahoo.com ; Tel.: 021-7656904/75817114 \\ Received: 1 Januari 2020; Accepted: 1 Maret 2020; Published: 15 Maret 2020
}

\begin{abstract}
Abstrak
Asap rokok menghasilkan radikal bebas yang menginduksi stres oksidatif sel sebagai penyebab penyakit. Paparan asap rokok yang terpapar secara terus menerus dalam tubuh berhubungan dengan kerusakan jaringan epitel mata akibat peroksidasi lipid, membentuk hiperosmolaritas air mata menjadi sindrom mata kering. Tujuan penelitian ini untuk mengetahui paparan asap rokok terhadap sindrom mata kering pada mahasiswa UPN"Veteran” Jakarta. Penelitian ini adalah analitik observasional dengan desain cross sectional, sampel mahasiswa UPN "Veteran" Jakarta sebanyak 70 mahasiswa, usia 18-24 tahun diambil secara stratified propotional random sampling. Pengambilan data dilakukan menggunakan kuesioner OSDI, serta menilai kekeringan mata menggunakan uji Schirmer. Hasilnya, frekuensi mahasiswa UPN "Veteran" Jakarta yang merokok masih kategori derajat ringan $80 \%$, lama merokok 5 tahun dan derajat sedang $20 \%$, lama merokok 6 tahun, Uji Chi-Square menunjukkan bahwa paparan asap rokok dapat menimbulkan sindrom mata kering $(\mathrm{p}=0,003)$, Menghindari asap rokok dan faktor resiko lainnya dapat menurunkan sindrom mata kering, dan diperlukan vitamin A untuk memperbaiki mata kering.
\end{abstract}

Kata kunci : Paparan asap rokok, radikal bebas, sindrom mata kering

\section{Pendahuluan}

Asap rokok mengandung lebih dari 4000 komponen berbahaya yang dapat mengganggu kesehatan antara lain, nikotin, tar, nitrosamin, polisiklik aromatik hidrokarbon (PAH), hidrogen sianida, karbon monoksida, akrolein, logam berat (kadmium, timbal, dan merkuri) dan formaldehida ${ }^{[1,2,3]}$. Tingginya jumlah perokok aktif di dunia sekitar 1,1 miliar dan 
sepertiganya aktif merokok pada usia 15 tahun. Indonesia menempati urutan pertama di dunia perokok laki-laki sekitar 67\%, namun berdampak juga bagi non perokok di lingkungan perokok Perilaku merokok pada usia di atas 15 tahun masih cenderung meningkat dari 34,2\% menjadi $36,3 \%$. Prevalensi sindrom mata kering berkisar antara 5\% sampai lebih dari 30\% pada rentang umur yang bervariasi. Sindrom mata kering pada populasi Asia lebih banyak dibandingkan dengan populasi kulit putih Kaukasia, dan dapat mengenai semua usia. ${ }^{[3,4,5]}$

Komposisi air mata terdiri dari 3 komponen yaitu lipid, aqueous, dan musin. Produksinya sekitar 1,2 $\mu \mathrm{l}$ per menit dengan volume total $6 \mu 1$. Tebal lapisan air mata diukur dengan interferometri adalah $6,0 \mu \mathrm{m}$ dan $\pm 2,4 \mu \mathrm{m}$ pada mata normal dan menurun menjadi 2,0 $\mu \mathrm{m} \pm 1,5 \mu \mathrm{m}$ pada pasien sindrom mata kering ${ }^{[4,5,6]}$ Asap rokok menyebabkan akomodasi penglihatan berkurang akibat evaporasi air mata yang berlebihan yang menggangu aktivitas kerja. $^{[4,5,6]}$

Faktor resiko mata kering berhubungan dengan asap rokok, udara kering, debu, usia, faktor hormonal, obat-obatan, pemakaian lensa kontak, operasi laser mata, penyakit autoimun, dan kelainan kelenjar lakrimal. ${ }^{[7,8,20]}$ Faktor gaya hidup merokok sebagai faktor resiko beberapa penyakit kronik, dan sindrom mata kering merupakan penyakit multifaktorial yang menyebabkan rasa ketidaknyamanan pada mata, gangguan penglihatan dan kestabilan jumlah air mata, yang berpotensi merusak permukaan mata disertai dengan peningkatan osmolaritas air mata dan inflamasi. ${ }^{[9,10,16]}$,

Asap rokok menyebabkan ketidakstabilan air mata dengan cara peroksidasi lapisan membran lipid pada air mata yang menyebabkan hiperosmolaritas, yang bila terus menerus terjadi berakibat menjadi sindrom mata kering. ${ }^{[10,11,12,13]}$ Lipid tersebut tersebar ke seluruh permukaan mata setiap kali berkedip, berfungsi mencegah penguapan dari lapisan aqueous dan mempertahankan ketebalan lapisan air mata sehingga lapisan air mata menyebar secara merata. Lapisan aqueous berfungsi mengikat oksigen dan karbondioksida, nutrisi, lisozim dan laktoferin berfungsi mempertahankan integritas permukaan mata normal. Lapisan lipid mempunyai tegangan permukaan rendah yang mampu meratakan penyebaran lapisan air mata sehingga permukaan air mata menjadi halus. ${ }^{[6,10]}$ Musin mencegah perlekatan dan interaksi dari mikroba, debris, dan sel-sel inflamasi terhadap sel epitel, memberikan viskositas yang melindungi epitel kornea dari kerusakan karena kedipan mata berulang, mencegah lapisan air mata berbentuk gumpalan pada kornea dan memastikan bahwa lapisan air mata melembabkan seluruh permukaan kornea dan konjungtiva. ${ }^{[10,11,14]}$ 
Asap rokok dapat menyebabkan sindrom mata kering pada usia muda. Perokok 1,5 kali lebih berisiko terkena sindrom mata kering dibandingkan dengan bukan perokok. ${ }^{[8,9,15]}$ Sindroma mata kering yang lebih lanjut rentan terkena infeksi yang dapat menyebabkan kebutaan seperti keratitis bakterial. ${ }^{[14,16]}$ Lapisan lipid yang rusak tersebut menyebabkan hilangnya penahan evaporasi pada aqueous air mata dan terjadi evaporasi berlebihan yang menyebabkan hiperosmolaritas air mata. Inflamasi dan rusaknya sel epitel kornea menyebabkan hilangnya lapisan musin air mata sehingga terjadi ketidakstabilan air mata dan rusaknya epitel dan timbul gejala-gejala dari sindrom mata kering. ${ }^{[6,14,16]}$

Sindrom mata kering mengalami penurunan produksi air mata atau evaporasi berlebihan,ditandai dengan rasa iritasi, berpasir, panas, berair, mata merah, glaukoma, peningkatan frekuensi berkedip, rasa lengket terutama pada saat bangun di pagi hari, dan kadang timbul rasa gatal, serta penglihatan kabur. ${ }^{[14,24\}}$ Sekresi air mata basal pada perokok berat lebih rendah dibandingkan perokok ringan. dan biasanya ditentukan oleh banyaknya jumlah rokok yang dihisap dan lamanya waktu merokok. Hiperosmolaritas air mata mengaktifkan jalur inflamasi yang dapat merangsang saraf kornea dan konjungtiva sehingga terasa panas, mata perih, rasa berpasir dan berkedip yang berlebihan. Pengeluaran air mata pada pasien sindrom mata kering dapat dilakukan menggunakan uji Schrimer. ${ }^{[19,23,25]}$

Tujuan penelitian mengetahui paparan asap rokok terhadap sindrom mata kering pada mahasiswa UPN "Veteran” Jakarta

\section{Metode penelitian}

Penelitian ini adalah analitik observasional dengan cross sectional, dengan populasi mahasiswa Universitas Pembangunan Nasional (UPN) "Veteran" Jakarta, diambil secara stratified propotional random sampling. Sampel berjumlah 70 mahasiswa sesuai kriteria inklusi usia 18-24 tahun, tidak memakai lensa kontak, tidak menderita penyakit mata merah, adanya radang mata atau alergi dan belum pernah menjalani operasi mata atau laser mata. Pengambilan data dengan menggunakan Kuesioner Ocular Surface Disease Index (OSDI) dan pengukuran sindrom mata kering diukur dengan menggunakan Tes Schirmer dengan cara meletakkkan strip kertas saring diselipkan pada kelopak mata dan ukur panjang kertas yang basah dalam waktu 5 menit (normal jika lebih $10 \mathrm{~mm}$ ).

\section{Hasil Penelitian}


Jumlah sampel penelitian adalah 70 orang mahasiswa UPN "Veteran" Jakarta, terdiri dari 16 orang Fakultas Ekonomi, 7 orang Fakultas Kedokteran, 5 orang Fakultas Teknik, 12 orang Fakultas Sosial dan Ilmu Politik, 7 orang Fakultas Ilmu Komputer, 9 orang Fakultas Hukum, dan 14 orang Fakultas Ilmu Kesehatan.

Usia mahasiswa rata-rata 18-24 tahun, tidak merokok $50 \%$ dan merokok $50 \%$ dengan kategori ringan sebanyak $80 \%$ dengan lama merokok sekitar 5 tahun dan perokok sedang 20 $\%$ dan lama merokok 6 tahun (merokok derajat ringan dan sedang menurut perhitungan Indeks Brinkman). Mahasiswa yang tidak merokok tetapi mengalami sindrom mata kering terdapat 8 $\%$. Mahasiswa yang mengalami sindrom mata kering untuk waktu satu minggu berdasarkan kuesioner OSDI sebanyak $73 \%$. Uji Schrimer mengalami sindrom mata kering $45 \%$ (Tabel 1)

Tabel 1. Gambaran usia, merokok dan sindrom mata kering

\begin{tabular}{lcc}
\hline & \multicolumn{2}{c}{$\begin{array}{c}\text { Frekuensi sindrom } \\
\text { mata kering }\end{array}$} \\
\cline { 2 - 3 } & Jumlah & $\%$ \\
\hline 1. Usia 18-24 tahun & & \\
2. Keadaan & & \\
$\quad$ Tidak merokok & 70 & 8 \\
Merokok & 70 & \\
ringan & 56 & 20 \\
sedang & 14 & \\
$\quad$ & 73 \\
Sindrom mata kering & & 45 \\
Kuesioner OSDI & & \\
Tes Schirmer & &
\end{tabular}

\section{Pembahasan}

Paparan asap rokok dalam tubuh dapat memberikan sindrom mata kering, karena radikal bebas yang dihasilkan dari asap rokok bereaksi dengan lipid membran epitel mata membentuk peroksidasi lipid, terjadi inflamasi yang mengakibatkan hiperosmolaritas mata dan berakhir menjadi sindrom mata kering. ${ }^{[3,4,6,8]}$ Sindrom mata kering pada mahasiswa yang tidak merokok ada $8 \%$, disebabkan udara kering, radiasi ultraviolet, asap kendaraan, terlalu lama menatap layar monitor laptop untuk membaca dan penggunaan hp menyebabkan mata terasa berpasir, iritasi, dan terasa panas. ${ }^{[3,4,5]}$

Paparan asap rokok baik keadaan ringan dengan waktu 5 tahun dan sedang dengan waktu 6 tahun dihasilkan $45 \%$ mahasiswa mengalami sindrom mata kering, namun pada pengukuran Tes Schirmer masih ada yang normal. Usia sekitar 18-24 tahun, terjadi regenerasi 
sel kelenjar lakrimal yang berkompensasi terhadap inflamasi pada awal paparan asap rokok, peningkatan refleks berkedip juga dapat menstimulasi saraf untuk memproduksi air mata. ${ }^{[8,9,10,11]}$ Obstruksi kelenjar lakrimal dapat disebabkan karena trauma, eritema multiform, dan trauma kimia ataupun trauma panas. Hiposekresi dapat disebabkan karena terhalangnya sensorik yang terjadi pada pasien diabetes melitus atau terhalangnya motorik yang disebabkan kerusakan saraf kranialis. ${ }^{[16,17,18]}$

Refleks berkedip dan stimulasi produksi air mata yang terus menerus menyebabkan kelelahan pada kelenjar lakrimal dan memberikan respon sitokin inflamasi neurogenik di kelenjar lakrimal sehingga menyebabkan penurunan sekresi kelenjar lakrimal. Gangguan fungsi lipid akan menyebabkan evaporasi berlebih sehingga terjadi hiperosmolaritas air mata yang mengaktifkan aliran inflamatori di permukaan mata dan melepaskan mediator inflamasi ke dalam air mata, dapat melukai epitel kornea dan konjungtiva sehingga menyebabkan apoptosis yang dapat memperparah hiperosmolaritas air mata. Mediator inflamasi yang dihasilkan dapat menstimulasi saraf pada kornea dan konjungtiva sehingga menimbulkan rasa tidak nyaman, rasa panas, rasa terbakar, perih, dan berpasir. ${ }^{[6,14,16,23]}$

Kerusakan terus menerus yang terjadi pada permukaan okular dapat menyebabkan metaplasia, dan jumlahnya lebih tinggi pada epitel permukaan konjungtiva pada perokok dibandingkan pada yang bukan perokok. Metaplasia skuamosa pada kasus yang lebih lanjut akan menyebabkan keratinisasi pada epitel mukosa konjungtiva, karena disebabkan oleh peningkatan peradangan akibat iritasi toksik yang ada pada asap rokok, yang berakibat pada tidak adanya faktor pertumbuhan yang diperlukan untuk diferensiasi epitel. ${ }^{[14,15,16]}$

Merokok dapat menurunkan densitas sel goblet, terjadi inflamasi jumlah sel goblet menurun karena sel goblet rentan terhadap pembengkakan. Selgoblet yang bengkak mudah sekali rusak sehingga tidak dapat memproduksi musin untuk melindungi epitel kornea dan konjungtiva. $^{[3,9,14,15]}$ Nikotin pada rokok juga dapat menstimulasi makrofag yang dapat mengubah protein matriks ekstraseluler, akan mempercepat proses apoptosis, yang meningkatkan hiperosmolaritas yang sudah terjadi akibat evaporasi berlebihan. Karbon monoksida yang terhirup dari asap rokok dapat menyebabkan berkurangnya kemampuan darah untuk membawa oksigen sampai ke kapiler-kapiler mata, terutama kelenjar lakrimal yang dapat menyebabkan penurunan fungsi lakrimal untuk memproduksi air mata. ${ }^{[7,15]}$ Hiperosmolaritas air mata, seperti yang sudah dijelaskan dapat mengaktifkan jalur inflamasi dan mengeluarkan mediator inflamasi. Inflamasi tersebut dapat menyebabkan luka epitel kornea dan konjungtiva sehingga menyebabkan apoptosis yang meningkatkan hiperosmolaritas air mata. Inflamasi 
yang terjadi dapat merangsang saraf kornea dan konjungtiva sehingga pasien merasakan rasa panas pada mata, mata merah, perih, dan rasa berpasir. ${ }^{[18,21,22]}$

Sindrom mata kering ditandai dengan rasa iritasi, berpasir, panas, berair, mata merah, peningkatan frekuensi berkedip, rasa lengket terutama pada saat bangun di pagi hari, kadang timbul rasa gatal, dan penglihatan kabur. Penyebab sindrom mata kering (sindrom Sjogren), karena autoimun yang menyerang kelenjar lakrimal dan kelenjar saliva serta organ tubuh lainnya, terdapat infiltrasi sel $\mathrm{T}$ aktif yang menyebabkan kematian sel-sel di dalam duktus sehingga menyebabkan hiposekresi. Sindrom mata kering non sindrom Sjogren karena defisiensi kelenjar lakrimal primer, defisiensi kelenjar lakrimal sekunder, obstruksi kelenjar lakrimal, dan refleks hiposekresi. ${ }^{[4,5,18]}$

Sindrom mata kering karena evaporasi berlebihan dapat dibagi menjadi penyebab intrinsik dan ekstrinsik. Penyebab intrinsik di antaranya yang pertama adalah disfungsi kelenjar meibom sehingga tidak terbentuk atau sedikitnya produksi lipid. Kedua, karena kelopak mata yang mengalami deformitas sehinggasaat berkedip mata tidak tertutup sempurna. Kebiasaan berkedip yang jarang juga dapat memperburuk sindrom mata kering. Penyebab ekstrinsik sindrom matakering adalah pemakaian kontak lensa, defisiensi vitamin A sehingga perkembangan dari sel goblet terganggu, obat-obatan topikal dan sistemik antihistamin, diuretik, polusi udara yang disebabkan karena asap rokok dan asap kendaraan. ${ }^{[6,16,22]}$

Ketidakstabilan airmata sehingga menyebabkan hiperosmolaritas yang mengakibatkan kerusakan pada permukaan epitel dengan mengaktifkan aliran inflamatori yaitu mitogenactivatedprotein (MAP) kinase dan nuclear factor (NF) kB signaling dipermukaan mata dan melepaskan mediator inflamasi (Interleukin 1, TNF alphadan matrix metallopeptidase (MMP) ke dalam air mata. Mediator inflamasi tersebut dapat merangsang saraf pada kornea dan konjungtiva, dan dapat menyebabkan penambahan luka pada epitel kornea dan konjungtiva sehingga sel goblet penghasil mukus rusak. ${ }^{[16,19,20]}$

Kerusakan pada epitel kornea dan konjungtiva menginduksi apoptosis serta rasa nyeri, dan meningkatkan hiperosmolaritas. Rangsangan saraf tersebut juga menyebabkan stimulasi produksi air mata dikelenjar lakrimal sehingga pada awal sindrom mata kering terjadi hipresekresi airmata. Refleks berkedip dan stimulasi produksi air mata yang terus menerus menyebabkan kelelahan pada kelenjar lakrimal, memberikan respon sitokin inflamasi neurogenik di kelenjar lakrimal dan menyebabkan penurunan sekresi kelenjar lakrimal. ${ }^{[4,6,15]}$

\section{Kesimpulan}


Radikal bebas dari paparan asap rokok bereaksi dengan lipid membran jaringan epitel mata membentuk peroksidasi lipid. Kerusakan pada epitel akbat inflamasi fungsional lakrimal kornea dan konjungtiva menginduksi apoptosis serta rasa nyeri, yang meningkatkan hiperosmolaritas mata mata yang menyebabkan sindrom mata kering. Paparan asap rokok menyebabkan sindrom mata kering. Menghindari paparan asap rokok dapat menurunkan sindrom mata kering, dan penyakit lainnya. Penambahan antioksidan vitamin A sangat membantu melindungi mata dari kerusakan radikal bebas asap rokok.

Conflicts of Interest: The authors declare no conflict of interest

\section{Daftar pustaka}

[1] WHO, Tobacco, 2017

[2] Tirtosastro, S, Murdiyati, AS. Kandungan Kimia Tembakau dan Rokok 2010 ; 2 (2) : 3343

[3] Calonge, M, Pinto FJ, Gonzalez-Garcia, MJ, Enriquez S, Rosa, ALdl, F I, Lopez MA. Effects of the External Environment on Dry Eye Disease. International Opthalmology Clinic $2017 ; 57$ (2) : 23-40

[4] Eva, PR, Whitcher, JP, Vaughan, Asbury. Oftalmologi umum. 2015 ; 17 : 21-34

[5] Ilyas, S, Yulianti SR. Ilmu Penyakit Mata 2015 ; 5 : 51-70

[6] Javadi, MA, Feizi, S. Dry Eye Syndrome. Journal of Ophthalmic and Vision Research $2011 ; 16: 192-198$

[7] Tiwari, S, Ali, MJ, Vemuganti, GK. Human lacrimal gland regeneration ; perspectives and review of literature. Saudy Journal of Ophthalmology $2014 ; 28: 12-18$

[8] Thomas, J, Jacob, GP, Lekha, A. The Effect of Smoking on the Ocular Surface and The Precorneal Tear Film. Australian Medical Journal 2012； 5 (6) : 221-226

[9] Uchino, Y, et.al. Impact of Cigarette Smoking on tear function and forrelation between conjunctival goblet cell and tear concentration in office Worker. Scientific Reports 2016 ; 9 (10) : 15-18

[10] Yamada, M, Mizuno, Y, Shigeyasu, C. Impact Of Dry Eye On Work Productivity. ClinicoRconomics and Putcomes Research $2012 ; 4: 307-312$

[11] Yoon, KC, Song, BY, Seo, MS. Effect of Smoking on tear film and ocular surface. Korean Journal of Ophthalmology $2015 ; 19: 18-22$

[12] Banerjee1.S, Jyotirmoy G, Parames CS, Drug Metabolism and Oxidative Stress: Cellular Mechanism and New Therapeutic Insights. J. Biochem Anal Biochem 2016 ; 5 (1) : 100 
[13] Birben E, et.al. Rev. Oxidative Stress and Antioxidant Defense, J World Allergy Organization 2012;

[14] Kuo Y-K, Lin I-C, Chien L-N, Lin T-Y, How Y-T, Chen K-H, et al. Dry Eye Disease: A Review of Epidemiology in Taiwan, and its Clinical Treatment and Merits. J Clin Med. $2019 ; 8(8): 1227$.

[15] Xu L, Zhang W, Zhu XY, Suo T, Fun XQ, Fu Y. Smoking and the risk of dry eye: A meta-analysis. Int J Ophthalmol. 2016 ; 9 (10): 1480-6.

[16] Mantelli F, Massaro-Giardano M, Macchi I, Lambiasa A, Bonini A. The cellular mechanism of dry eye ; from phatogenesis to treatment. J Cell Physiol 2013 ; 228 (12) : 2253-2256

[17] Lee SY, Petznick A, Tony L. Associations of systemic diseases, smoking and contact lens wear with severity of dry eye. Ophthalmic physiol Opt $2012 ; 32$ (6) : 518 - 526

[18] Sayin N, Kara N, Peku G, Altinkaynak H, Effects of chrome smoking on central corneal thickness, endothelial cell, and dry eye parameters. Cutan Ocul Toxicol 2014 ; 33 (3) : 201-205

[19] Zeev MS Ben, Miller DD, Latkany R. Diagnosis of dry eye disease and emerging technologies. Clin Ophthalmol. $2014 ; 8$ : 581-90.

[20] Stern ME, Schaumburg CS, Pflugfelder SC. Dry eye as a mucosal autoimmune disease. Int Rev Immunol. 2013 ; 32 (1) :19-41.

[21] Castro JS, Selegatto IB, Castro RS, Miranda ECM, Vasconcelos JPC, Carvalho KM, et al. Prevalence and risk factors of self reported dry eye in Brazil. Sci Rep 2018 ; 8 (1) : 210 .

[22] Law SM, Lu X, Yu F, Tseng V, Law SK, Coleman AL. Cigarette smoking and glaucoma in the United States population. Eye. 2018 ; 32 (4) :716-25.

[23] Scott, GA, Catania, LJ, Larkin, KM, Melton, R, Semes, LP, Shovlin, JP. Care of the Patient with Ocular Surface Disorders. American optometric 2011

[24] Friedman, NJ. Impact of dry eye disease and treatment on quality of life. Current opinion in opghthalmology $2010 ; 21(4): 310-316$.

[25] Hosaka, E, Kawamorita, T, Ogasawara, Y, Nakayama, N, Uozato, H, Shimizu, K, Dogru, M, Tsubota, K, Goto, E. Interferometry in the evaluation ofprecorneal tear film thickness in dry eye. American journal of ophthalmology $2011 ; 151: 18-23$

[26] Dahlan, S, Statistik untuk kedokteran dan kesehatan deskriptif, bivariat, dan multivariate $2014 ; 6$ 